\title{
Use of tyrosine kinase inhibitor by patients with chronic myeloid leukemia at a public hematology institution in the state of Amazonas, Brazil
}

\author{
Andreia Duarte MENEZES ${ }^{1}$ (D), Nelson Abrahim FRAIJI ${ }^{1,2}$ (D) \\ ${ }^{1}$ Programa de pós-graduação em Ciências Aplicadas à Hematologia da Universidade do Estado do Amazonas ${ }^{2}$ Fundação hospitalar de \\ Hematologia e Hemoterapia do Amazonas
}

Corresponding Author: Menezes AD, andreiadmenezes@yahoo.com.br

Submitted 22-07-2020 Resubmitted: 10-10-2020 Accepted: 18-10-2020

Peer review: blind reviewers

\begin{abstract}
Objectives: To evaluate the conditions of use of tyrosine kinase inhibitors and adherence by patients with chronic myeloid leukemia treated at a public hematology institution. Methods: This was an observational and cross-sectional study carried out from December 2015 to April 2016. Data collection was carried out through interviews with standardized questionnaires that assessed the socioeconomic and demographic profile, drug therapy and by the Morisky-Green test that assessed the green adherence. Patients over 18 years old who had been using one of the tyrosine kinase inhibitors for more than one month were included; imatinib, dasatinib or nilotinib and who signed the informed consert form, agreement to participate in study. Descriptive statistical analysis and chi-square test with Yates correction were performed. Results: 63 patients were interviewed, with a mean age of 50 years with a standard deviation of 15.95 . being $60 \%$ men. As for knowledge about the aspects related to the use of inhibitors: $95.2 \%$ took at the right time, $93.7 \%$ did not use other medications concomitantly, 63.5\% kept it in an appropriate place and $97 \%$ of the patients received prior guidance from the doctor about the use. As for information about treatment, $90.5 \%$ knew the purpose of taking the medication, $60 \%$ did not know the time of use, $83 \%$ did not know what would happen if they stopped taking it and $73 \%$ believed they could stop the treatment at some point. Adherence to treatment was identified $46 \%$ of patients. Conclusion: No statistically significant differences were found between having or not adherence, when compared with the studied variables.
\end{abstract}

Keywords: tyrosine kinase inhibitors, chronic myeloid leukemia, pharmacological treatment.

\section{Uso de inibidor de tirosina quinase por pacientes com leucemia mieloide crônica em uma instituição pública de hematologia do estado do Amazonas, Brasil}

\begin{abstract}
Resumo
Objetivos: Avaliar as condições de uso dos inibidores de tirosina quinase e a adesão por portadores de leucemia mieloide crônica atendidos em uma instituição pública de hematologia. Métodos: Tratou-se de um estudo observacional e transversal realizado de dezembro de 2015 a abril de 2016. A coleta de dados foi através de entrevistas com questionários padronizados que avaliaram o perfil socieoeconômico e demográfico, a terapia medicamentosa e pelo teste de Morisky-Green que avaliou o grau de adesão. Foram incluídos pacientes com mais de 18 anos em uso há mais de um mês, de um dos inibidores de tirosina quinase; imatinibe, dasatinibe ou nilotinibe e que assinaram o termo de consentimento livre esclarecido, de concordância de participação do estudo. Foi realizada a análise estatística descritiva e o teste do qui-quadrado com correção de Yates. Resultados: Foram entrevistados 63 pacientes, com média de idade de 50 anos com desvio-padrão de 15,95. sendo 60\% homens. Quanto ao conhecimento sobre os aspectos relacionados ao uso dos inibidores: 95,2\% tomaram no momento correto, 93,7\% não usaram concomitantemente outros medicamentos, $63,5 \%$ guardavam em local adequado e $97 \%$ dos pacientes receberam orientação prévia do médico sobre o uso. Quanto à informação sobre o tratamento, $90,5 \%$ conheciam a finalidade de tomar o medicamento, $60 \%$ não sabiam o tempo de uso, $83 \%$ não sabiam o que aconteceria se parassem de tomar e $73 \%$ acreditavam poder interromper o tratamento em algum momento. Identificou-se uma adesão ao tratamento de $46 \%$ dos pacientes. Conclusão Não foram encontradas diferenças estatisticamente significativas entre ter ou não adesão, comparando-se com as variáveis estudadas.
\end{abstract}

Palavras-chave: inibidores de tirosina quinase, leucemia mieloide crônica, tratamento farmacológico. 


\section{Introduction}

Chronic Myeloid Leukemia (CML) is a hematological neoplasm cytogenetically characterized by the presence of the Philadelphia chromosome and the production of a protein with increased tyrosine kinase activity ${ }^{1,2}$ and represents 15 to $20 \%$ of all leukemias. ${ }^{3}$

The drugs most used in the treatment of $C M L$ are tyrosine kinase inhibitors (TKIs): imatinib mesylate, dasatinib, nilotinib, bosutinib and ponatinib. These represent an important advancement in treatment, as they allow the patients survival rates practically similar to that of the general population. ${ }^{4,5}$

The analysis of drug safety is one of the instruments available to health systems that significantly help the optimization of pharmacotherapy and its rational use. This, in turn, comprises the selection of drugs that meet not only safety criteria, but also quality, effectiveness and pharmacotherapeutic follow-up, which aims to identify and prevent negative outcomes associated with drug treatment. ${ }^{6}$

The CML patient needs assistance not only for the symptoms and complications of the disease, but also for comorbidities that determine the continuous use of the drug with possibilities of interactions, as well as the toxicity of the antineoplastic treatment, adverse reactions, self-medication and alternative treatments. The patient's understanding of the prescription is essential to ensure adherence to the treatment. ${ }^{8}$

The evaluation methods proposed to assess adherence to the treatment can be direct (dosages of drugs or metabolites, dosage of a marker in the blood) or indirect (questionnaires, patient diaries, pill count, electronic monitoring of medication and evaluation of clinical response). ${ }^{9.10}$ A widely used evaluation method is the indirect test by Morisky and Green (TMG), which uses standardized questions about the reasons that can hinder treatment. ${ }^{11}$

In CML, adherence is essential for a successful treatment based on TKIs, and the evidence suggests that reduced adherence is associated with reduced efficacy and increased health costs. ${ }^{12}$

Considering the importance of tyrosine kinase inhibitors in the treatment, this study aimed to analyze the conditions of use of these drugs and their adherence by CML patients in a public hematology institution in the state of Amazonas.

\section{Methods}

This was an observational and cross-sectional study carried out at Fundação Hospitalar de Hematologia e Hemoterapia do Amazonas (FHEMOAM), a medium-sized institution that monitors patients with benign and malignant hematological diseases. FHEMOAM has outpatient clinics and wards that offer specialized treatments, emergency care, pharmaceutical, dental, and physical therapy, as well as psychological and social support. It also carries out research and teaching activities.

The study was carried out from December $14^{\text {th }}, 2015$ to April $26^{\text {th }}, 2016$, with $\mathrm{CML}$ patients who met the following inclusion criteria: being 18 years of age or older, being in treatment for more than one month with one of the tyrosine kinase inhibitors (TKIs): imatinib, dasatinib or nilotinib, and who signed the Free and Informed Consent Form (FICF). Patients under 18 years of age and those who had been using one of the drugs for less than a month were excluded because it would prevent the assessment of adherence to the treatment.
The interviews were conducted with two instruments. The first addressed data from the sociodemographic and economic profile with independent variables. The second referred to obtaining data related to drug therapy, conditions of use of drugs at home and knowledge about the disease, adapted from the questionnaires by Dewulf (2005) ${ }^{13}$ and Volpe (2007). ${ }^{14}$ Regarding the questionnaire on drug therapy, aspects related to the independent variables were addressed (according to the patients' report): type of TKI used (imatinib, dasatinib or nilotinib), time of use (months or years); if the patient received guidance on the purpose of use (yes, from whom); if there were adverse reactions (if yes, which ones), about the time of administration (time and whether with meals or not), liquid ingestion (water or other) and quantity (less than one glass, one glass or more than one $180 \mathrm{~mL}$ glass); whether the supplier of the medication was known (local, state or federal government); if it was difficult to get the medication, the place where the medication was stored, the purpose of taking the TKI, if the patient knew how long they would use the TKI; if they stopped using it (positive answer, asked why); if they knew the consequences of the suspension, and if they believed that they could interrupt the treatment in the future (if the answer was affirmative, asked why). In addition to these, the Morisky and Green (1986) test ${ }^{11}$ was also used.

Convenience sampling was used, non-probabilistic. Thus, the sample had $63 \mathrm{CML}$ patients who met the criteria and accepted to participate in the research. The interviews were conducted in the outpatient clinic, while the patients waited for medical care. Each questionnaire was read and completed by the same researcher, according to each answer provided by the patient. The individual interview lasted a mean of 15 minutes

The simple and relative absolute frequencies were calculated for the categorical data and, at the crossing of the variables, the chisquare test with Yates correction was applied. The software used in data analysis was the Epi Info program, version 7.2 for Windows. The level of significance set for the aplication of the tests was $5 \%$.

This study was approved by the Research Ethics Committee of Fundação Hospitalar e Hemoterapia do Amazonas (FHEMOAM), under CAAE No. 48313015.3.000.0009.

\section{Results}

Among $133 \mathrm{CML}$ patients using one of the TKIs, 63 were interviewed. Of these, 38 (60\%) were men. The mean age of the patients was 50 years old, with a deviation of 15.95. The youngest patient was 21 years old and the oldest, 85 .

Regarding the use of TKIs, $65 \%$ of the CML patients used imatinib, $17.5 \%$ nilotinib and $17.5 \%$ dasatinib. Regarding the daily dose of the TKI, all the respondents were able to mention it. Regarding the time of administration, most of the patients (95.2\%) followed what was specified in the package insert. In addition, a large part (90.5\%) drank it with the appropriate liquid, water, but only $58.7 \%$ drank the amount of one glass or more.

As for the knowledge about the purpose of taking TKIs, 90\% of the patients said that they knew and mentioned that it was to treat CML but, of these, $4 \%$ did not know how to specify the type of leukemia. As for the time they would use the antineoplastic, only $40 \%$ stated knowing and said it would be for life.

93.7\% used some medication but only $6.3 \%$ used it concomitantly, with the therapeutic classes mentioned being analgesic, antihypertensive, antacid and oral antidiabetic. 
Our study assessed the use of TKIs and the level of information regarding treatment. More than half of the patients had adverse reactions to TKIs, the most cited being nausea, diarrhea, vomiting and headache, Table 1.

As for adherence to drug therapy, $54 \%$ of the respondents were nonadherent and $46 \%$, adherent. Patients was considered adherent only when they answered negatively to all four questions in the Morisky and Green test. The main causes of non-adherence according to the test were the following: forgetfulness (38\%), neglect regarding time (32\%), feeling bad (18\%) and feeling good (12\%).

Based on the result of the adherence assessment, some of the sociodemographic, economic and treatment status variables were compared. No statistical significant differences were found $(p>0.05)$ between the variables analyzed and total adherence or non-adherence: Table 2.

\section{Discussion}

The understanding of the prescription can be verified when assessing the patients' knowledge about the name, dose, duration and purpose of their treatment ${ }^{15}$. According to Piette et al (2006), ${ }^{16}$ the inappropriate use of medications by patients with chronic diseases, in terms of how to use them, should not be associated only with costs, but analyzed in a broader context, in which individual characteristics are observed (demographic, socioeconomic and clinical), as well as characteristics of the treatment, the care process and the health service in which the patient is included.

As for knowledge about the time of administration, administration liquid and amount of liquid ingested, more than half of the patients followed what was specified in the TKI package insert, which demonstrates an important initial understanding of the pharmacotherapy.
Table 1. Characteristics regarding the use and knowledge about TKIs by CML patients at the HEMOAM Foundation, Manaus-AM $(n=63)$.

\begin{tabular}{|c|c|}
\hline Information & $\begin{array}{l}\text { Patients } \\
(N=63) \\
\%(n)\end{array}$ \\
\hline \multicolumn{2}{|l|}{ Education, autonomy and beliefs about the treatment } \\
\hline \multicolumn{2}{|l|}{ Did you receive previous guidance? } \\
\hline Physician & $96.8(61)$ \\
\hline Pharmacist & $1.6(1)$ \\
\hline No & $1.6(1)$ \\
\hline Knows the purpose of taking TKIs ${ }^{1}$ & $90.5(57)$ \\
\hline Knows how long they will take the TKI ${ }^{1}$ & $40.0(25)$ \\
\hline Knows what happens if they stop taking TKI ${ }^{1}$ & $83.0(52)$ \\
\hline $\begin{array}{l}\text { Is aware that the inappropriate use of TKIs can com- } \\
\text { promise the success of the treatment }^{1}\end{array}$ & $93.7(59)$ \\
\hline $\begin{array}{l}\text { Believes that at some point they may stop treatment } \\
\text { with TKI }\end{array}$ & $73.0(46)$ \\
\hline \multicolumn{2}{|l|}{ Pharmacotherapy data } \\
\hline Do you know who provides your medications? ${ }^{1}$ & $42.9(27)$ \\
\hline It is difficult to get the TKIs ${ }^{1}$ & $43.0(27)$ \\
\hline Suitable storage location ${ }^{1}$ & $63.5(40)$ \\
\hline Uses other medications ${ }^{1}$ & $54.0(34)$ \\
\hline Adequate liquid used for medication use & $90.5(57)$ \\
\hline Adequate quantity of liquid used & $58.7(37)$ \\
\hline Adequate time of administration ${ }^{1}$ & $95.2(60)$ \\
\hline Takes the TKI concomitantly with some other medication ${ }^{1}$ & $6.3(4)$ \\
\hline \multicolumn{2}{|l|}{ Most cited adverse reactions ${ }^{1}$} \\
\hline Nausea & $38.1(24)$ \\
\hline Diarrhea & $22.2(14)$ \\
\hline Vomiting & $20.6(13)$ \\
\hline Cephalea & $17.5(11)$ \\
\hline Tiredness & $15.9(10)$ \\
\hline Abdominal pain & $15.9(10)$ \\
\hline Fever & $14.3(9)$ \\
\hline Swelling & $14.3(9)$ \\
\hline Cramps & $6.3(4)$ \\
\hline Dizziness & $6.3(4)$ \\
\hline
\end{tabular}

Table 2. Sociodemographic and treatment adherence profile of patients with CML treated at the HEMOAM Foundation, Manaus-AM, from December 2015 to April 2016.

\begin{tabular}{|c|c|c|c|c|}
\hline \multirow[b]{2}{*}{ Variables $(n=63)$} & \multirow[b]{2}{*}{$\begin{array}{l}\text { All } \\
N=63 \\
\%(n)\end{array}$} & \multicolumn{2}{|c|}{ Adherence } & \multirow[b]{2}{*}{ p-value } \\
\hline & & $\begin{array}{l}\text { No } \\
N=34 \\
\%(n)\end{array}$ & $\begin{array}{l}\text { Yes } \\
N=29 \\
\%(n)\end{array}$ & \\
\hline \multicolumn{5}{|l|}{ Sociodemographic and economic } \\
\hline \multicolumn{5}{|l|}{ Age group } \\
\hline $20-40$ & $31.7(20)$ & $20.6(13)$ & $11.1(7)$ & \\
\hline $41-59$ & $33.3(21)$ & $14.3(9)$ & $19.0(12)$ & 0.363 \\
\hline Male gender & $60.3(38)$ & $27.0(17)$ & $33.3(21)$ & 0.120 \\
\hline Income Range $\leq 1$ minimum wage ${ }^{1,2}$ & $46.0(29)$ & $55.9(19)$ & $34.5(10)$ & 0.148 \\
\hline Schooling over 8 years of study ${ }^{1}$ & $47.6(30)$ & $44.1(15)$ & $51.7(15)$ & 0.727 \\
\hline Origin & & & & 0.510 \\
\hline Inland of the state & $25.0(16)$ & $20.6(7)$ & $31.0(9)$ & \\
\hline Manaus & $75.0(47)$ & $79.4(27)$ & $60.0(20)$ & \\
\hline \multicolumn{5}{|l|}{ Education, autonomy and beliefs about the treatment } \\
\hline Believes that at some point they may stop treatment with TKI & $73.0(46)$ & $73.5(25)$ & $72.4(21)$ & 0.998 \\
\hline \multicolumn{5}{|l|}{ Pharmacotherapy data } \\
\hline Uses other medications ${ }^{1}$ & $54.0(34)$ & $52.9(18)$ & $55.2(16)$ & 0.998 \\
\hline Adequate time of administration ${ }^{1}$ & $95.2(60)$ & $49.2(31)$ & $46.0(29)$ & 0.296 \\
\hline Reported adverse reactions $^{1}$ & $75.0(47)$ & $73.5(25)$ & $75.9(22)$ & 0.998 \\
\hline It is difficult to get the TKIs ${ }^{1}$ & $43.0(27)$ & $17.5(11)$ & $25.4(16)$ & 0.117 \\
\hline
\end{tabular}


Intake of the TKI at the specific time and with the appropriate amount of water leads to a lower risk of gastrointestinal disorders.

When making a comparison with previous studies carried out over the last 17 years, ${ }^{15,17,18}$ with patients on continuous use of medications, at different times, it was noticed that the $\mathrm{CML}$ patients of the HEMOAM Foundation, in relation to the knowledge variables about the use, duration and purpose of treatment, knew more about the pharmacotherapy.

As for the storage of TKIs, most of the respondents kept the medication properly. Among those who kept it in an incorrect manner, we identified the following: out of the original packaging, storage of medications in bathrooms and kitchens (humid places) and in places with easy access to children. According to the WHO, deficient packaging of medications can render them ineffective or have serious consequences for the health of the individual if ingested in the wrong way. ${ }^{19}$

In our study, most of the patients mentioned having adverse reactions, and higher frequencies of reactions were found related to gastrointestinal disorders, mainly nausea, diarrhea and vomiting, similar to those mentioned in the study by Rea (2015). ${ }^{20}$ According to Pinilla-lbaaz et al (2015), ${ }^{21}$ adverse reactions associated with therapy with TKIs can be managed by careful monitoring or dose adjustments.

As for the simultaneous use of TKIs with other medications, only $6 \%$ of the patients used them. The point is that the fact that TKIs are used for long periods can influence the risk of interactions. In an INCA study (between 2008 and 2009) on prescription drugs, $36 \%$ had a potential risk of interaction with imatinib. ${ }^{22,23}$

Regarding the question about what would happen if they voluntarily stopped taking the TKI, more than half of the patients stated knowing what would happen, which corroborated with the study by Hamerschlak and collaborators ${ }^{24}$ with 1,102 patients with CML registered in the Brazilian Association Lymphoma and Leukemia (Associação Brasileira de Linfoma e Leucemia, ABRALE), which assessed patients' perceptions of the disease, diagnosis, monitoring, treatment and adverse reactions.

The question on the belief of being able to interrupt the treatment in the future was also evaluated, most believed it was possible, the following being mentioned as reasons: cure given by God, followed by the response to the treatment, transplantation and change to a more innovative medication. The patients perception contradicted the recommendations of the National Comprehensive Cancer Network and the European Leukemia Network that there is an indefinite maintenance of the use of TKIs, even in patients who present a good therapeutic response. ${ }^{25,26}$

When assessing whether the patients knew who the supplier of their medication was, we indirectly aimed to check the patients' perception of the cost. Less than half of those interviewed knew it was the federal government. Much is discussed about the high cost of TKIs, but not always it is known how much the patient is informed of this expense, which in a way could even influence greater adherence to the treatment.

As for previous information received on the use of TKIs, almost all the patients mentioned that they were given by the physician. And the negligible mention of the pharmacist is surprising since, for more than a decade, in large hospitals throughout Brazil, there has already been an active and evident participation in pharmacotherapeutic monitoring and consequent pharmaceutical care. The result of the negligible participation of the pharmacist in HEMOAM, regarding the orientation to the use of medications, did not follow the evidence of the studies by Vinholes et al (2009), Simons et al (2011), Liekweg et al (2012), Oliveira et al (2013) and Ruiz et al. (2015), who showed greater participation by the pharmacist in therapeutic adherence. ${ }^{27,28,29,30,31}$

In the clinical practice, the patient's difficulty in using the prescribed medication is a present problem and, therefore, it is estimated that only $1 / 3$ of the patients present adequate adherence. ${ }^{32}$ Adherence to the use of medications has been studied for a long time and discussed in the literature by countless professionals. Its importance is crucial for the treatment of the patients and for the improvement of their health status. ${ }^{33}$

In our study, complete adherence was greater than $1 / 3$, which can be related to the fact that most of the patients have used the TKI for more than a year; this result was similar to other studies. ${ }^{34,35}$

Unintentional causes, forgetfulness or neglect regarding time were the main factors responsible for non-adherence, in our research. According to Marques and Pierin (2008), ${ }^{36}$ the largest barriers to antineoplastic adherence are the following: forgetting the time to take the medication and state of health (when they feel good or bad, they stop), for Efficace et al (2014), ${ }^{37}$ most CML patients are non-adherent due to unintended causes.

A comparison was made between adherence or non-adherence to the treatment and the sociodemographic and economic variables and the treatment situation, and no significant differences were found in the relationship between these factors. This corroborated with the study by Strelec $(2003)^{38}$, which found no association between demographic factors and adherence to drug therapy.

The present study had a higher percentage of patients who had complete adherence and greater performance but, when making a statistical comparison between the variables (adherence or non-adherence), there was no great significance. In contrast, the study by Sabate $(2003)^{39}$ mentions that it is possible that the higher the performance, the greater the adherence to drug treatment.

In another study, ${ }^{40}$ better adherence was found among patients who understood the severity of their disease, trusted their physician and believed in the effectiveness of the recommended therapeutic measures. It is understood that a detailed explanation of the advantages and disadvantages of the medication is considered the basis for improving agreement in the drug-adherence relationship. In this context, the work of a multidisciplinary team, which includes the pharmaceutical professional, can lead to the optimization of treatment and to greater adherence, which represents an effective way to reduce morbidity and mortality.

It is noticed that interventions to optimize adherence tend to be more effective when adapted to individual needs and perceptions about the treatment and linked to the factors that prevent or allow adherence. ${ }^{41}$

As for the limitations of our study, we can considerthe following: convenience sampling, which limits the results to the population studied; interviews being conducted in the outpatient clinic, at a single moment, which may have caused memory inaccuracy in some answers, and the short period of the research, since some patients from the most distant inland cities only return to consultations every 3 months. 


\section{Conclusion}

Adherence to drug therapy was $46 \%$; no statistically significant differences were identified between adherence or non-adherence to drug therapy and the variables studied. This can be related to the small sample size of our study, which somehow limits comparisons.

\section{Funding sources}

The project did not receive any funding.

\section{Collaborators}

ADM participated in the conception of the project; data collection, data analysis and interpretation, writing of the article, and critical review. NAF participated in the conception of the project, critical review and approval of the final version to be published. All the authors approved the final version to be published and assume responsibility for all the information of the paper, ensuring the accuracy and integrity of any of its parts.

\section{Acknowledgments}

To Fundação Hospitalar e Hemoterapia do Amazonas for allowing us to conduct the research. To Prof. Dr. Erich Vinícius de Paula for his suggestions in the elaboration of this research study.

\section{Conflicts of interest statement}

The authors declare that there are no conflicts of interest regarding this article.

\section{References}

1. Zago MA, Falcão RP, Pasquini R. Tratado de hematologia, 2a edição. São Paulo: Atheneu; 2014.

2. Bollmann PW, Giglio AD. Leucemia mieloide crônica: passado, presente, futuro. Einstein. 2011;9(2):236-243.

3. Bortolheiro TC, Chiattone CS. Leucemia mileoide crônica: história natural e classificação. Rev Bras Hematol Hemoter. 2008;30(1):3-7.

4. Cortes J, Kantaijian H. How I treat newly diagnosed chronic phase CML. Blood. 2012;120(7):1390-1397.

5. Mauro MJ. Goals for chronic myeloid leukemia TK Inhibitors treatment: how little diseases is too much? American Society of Hematology Education Program. 2014;1: 234-9.

6. Mastroianni P, Varallo FR. Farmacovigilância para a promoção do uso correto de medicamentos,1a edição. Porto Alegre: Artmed; 2013.

7. Dalla E, Couto DHN, Cava CEM, et al. Atenção farmacêutica aos pacientes com Leucemia Mielóide Crônica (LMC) em tratamento com dasatinibe no $\mathrm{HCl} / \mathrm{INCA} / \mathrm{MS}$. In: Atenção farmacêutica aos pacientes com Leucemia Mielóide Crônica (LMC) em tratamento com dasatinibe no HCI/INCA/MS. 2010.

8. Carvalho VT, Cassiani SDB, Chiericato $C$, et al. Erros mais comuns e fatores de risco na administração de medicamentos em unidades básicas de saúde. Rev Latino-Am Enfermagem. 1999;7(5):67-75.

9. Osterberg L, Blaschke T. Adherence to medication. N Engl J Med 2005;353(5):487-497

10. Freitas JGA, Nielson SEDO, Porto CC. Adesão ao tratamento farmacológico em idosos hipertensos: uma revisão integrativa da literatura. Rev Soc Bras Clín Méd. 2015;13(1):75-84.

11. Morisky DE, Green LW, Levine, DM. Concurrent and predive validatity of a self- reported measure of medication adherence. Medical Care. 1986;(24):67-74.

12. Jabbour E, Saglio G, Radich J, et al. Adherence to BCR-ABL inhibitors: issues for CML therapy. Clin Lymphoma Myeloma Leuk. 2012;12(4):223-229.

13. Dewulf NLS. Investigação sobre a adesão ao tratamento medicamentoso em pacientes com doenças inflamatórias intestinais [Dissertação (mestrado em ciências médicas)]. Universidade de São Paulo, Faculdade de Medicina de Ribeirão Preto, 2005.

14. Volpe CRG. Análise das condições de uso de medicamentos por idosos atendidos em ambulatório de hospital universitário. [Dissertação (mestrado em ciências médicas)]. Universidade de São Paulo, Faculdade de Medicina de Ribeirão Preto, 2007.

15. Da Silva TD, Schenkel EP, Mengue SS. Nível de informação a respeito de medicamentos prescritos a pacientes ambulatoriais de hospital universitário. Cad Saúde Pública. 2000;16(2):449455.

16. Piette JD, Heisler M, Horne R, et al. A conceptually based approach to understanding chronically ill patients' responses to medication cost pressures. Social science \& medicine. 2006;62(4):846-857.

17. Fröhlich SE, Dal Pizzol TDS, Mengue SS. Instrumento para avaliação do nível de conhecimento da prescrição na atenção primária. Rev Saúde Pública. 2010;44(6):1046-1054.

18. Pinto IVL, Moreira Reis AM, Almeida-Brasil CC, et al. Avaliação da compreensão da farmacoterapia entre idosos atendidos na Atenção Primária à Saúde de Belo Horizonte, MG, Brasil. Ciênc Saúde Coletiva. 2016;21(11): 3469-3481.

19. World Health Organization. (WHO) Medicines strategy 20042007: countries at the core, 2004.

20. Rea D. Management of adverse events associated with tyrosine kinase inhibitors in chronic myeloid leukemia. Annals of hematology. 2015;94(2):149-158.

21. Pinilla-Ibarz J, Sweet K, Emole J, et al. Long-term BCR-ABL1 tyrosine kinase inhibitor therapy in chronic myeloid leukemia. Anticancer research. 2015;35(12):6355-6364.

22. Cava PKP, Cava CEM, Winkelmann L, et al. Perfil farmacoepidemiológico dos pacientes com leucemia mielóide crônica (LMC) em tratamento com mesilato de imatinibe no hospital do câncer/INCA. Sistema Nervoso. 2010;8:15.

23. Haoula A, Widmer N, Buchasa MA, et al. Drug interactions with the tyrosine kinase inhibitors imatinib, dasatinib e nilotinib. Blood. 2011;117(8):675-87. 
24. Hamerschlak N, Souza C, Cornacchioni AL, et al. Patients perceptions about diagnosis and treatment of chronic myeloid leukemia: a cross sectional study among brazilian patients. Sao Paulo Med J. 2014;133(6):471-479.

25. Baccarani M, Deininger MW, Rosti G, et al. European Leukemia Net recommendations for the management of chronic myeloid leukemia. Blood. 2013;122(6):872-884.

26. National Comprehensive Cancer Network. NCCN Clinical Practice Guidelines in Oncology. Chronic Myeloid Leukemia. Version 2. 2017. Available in: https://www.nccn.org/professionals/physician_gls/pdf/cml .pdf. Accessed on: 15 feb 2015.

27. Vinholes GR, Alano GM, Galto D. A percepção da comunidade sobre a atuação do serviço de atenção farmacêutica em ações de educação e saúde relacionados à promoção do uso racional de medicamentos. Saude Soc. 2009;8(2):293-303.

28. Simons S, Ringsdorf $S$, Braun $M$, et al. Enhancing adherence to capecitabine chemotherapy by means of multidiscciplinary pharmaceutical care. Support Care Cancer. 2011;19(7):100918.

29. Liekweg A, Westfeld M, Braun M et al. Pharmaceutical care for patients with breast and ovarian cancer. Supportive Care in Cancer. 2012; 20(11):2669-2677.

30. Oliveira A, Munhoz EC, Nardin JM, et al. Avaliação de adesão ao mesilato de imatinibe de pacientes com leucemia mieloide crônica. Rev Bras Farm Hosp Serv Saúde. 2013;4(3):6-12.

31. Ruiz BSJ, Lemus MAG, Echeverri MPF. Atención farmacéutica y envío domiciliario de medicación a pacientes con leucemia mieloide crónica. Farm Hosp. 2015;39(01):13-22.

32. Valle EA, Viegas EC, Castro CAC, et al. A adesäo ao tratamento. Rev Bras Clín Ter. 2000;26(3):83-86.

33. Mourão-Júnior CA, Souza ABD. Adesão ao uso de medicamentos: algumas considerações. Estudos Interdisciplinares em Psicologia. 2010;1(1):96-107.

34. Anderson KR, Chambers CR, Lam N, et al. Medication adherence among adults prescrited imatinib, dasatinib or nilotinib for the treatment of chronic myeloid leukemia. Journal Oncology Pharmacy Practice. 2014;21(1):19-25.

35. Trivedi $D$, Landsman-Blumberg $P$, Darkow $T$, et al. Adherence and persistence among chronic myeloid leukemia patients during second-line tyrosine kinase inhibitor treatment. Journal of Managed Care Pharmacy. 2014;20(10):1006-1015

36. Marques PAC, Pierin AMG. Fatores que influenciam a adesão de pacientes com câncer à terapia antineoplásica oral. Acta Paul Enferm. 2008;21(2):323-329.

37. Efficace F, Rosti G, Cottone F, et al.Profiling chronic myeloid leukemia patients reporting intentional and unintentional non-adherence to lifelong therapy with tyrosine kinase inhibitors. Leukemia research. 2014;38(3):294-298.

38. Strelec MAAM, Pierin AM, Mion Júnior D. A influência do conhecimento sobre a doença e a atitude frente à tomada dos remédios no controle da hipertensão arterial. Arq Bras Cardiol. 2003;81(4):343-54.

39. Sabaté E. Adherence to long-term therapies: evidence for action. In: World Health Organizations. Genova, 2003. p211.
40. Laufs $U$, Rettig-Ewe $V$, Böhm M. Strategies to improve drug adherence. European Heart Journal. 2011;32(3):264-268.

41. Miasso Al, Miamoto CS, do Carmo Mercedes BP, et al. Adesão, conhecimento e dificuldades relacionados ao tratamento farmacológico entre pessoas com esquizofrenia. Rev Eletrônica Enferm. 2015;17(2):186-95 